\title{
BESTRIJDING VAN DOPLUIS OP PERZIK EN DRUIF.
}

De zeer gunstige resultaten, die met het gebruik van carbolineum op verschillende gewassen, ter bestrijding van dierlijke parasieten (meest blad- en schildluizen en mijten) verkregen zijn, hebben het vertrouwen in dit middel bij de practische tuinbouwers zeer doen toenemen. Daardoor is het mogelijk geweest, door proefnemingen in de practijk op vrij ruime schaal na te gaan, of van de groote insectendoodende kracht ervan nog meer partij kon worden getrokken. Dat de practici zich daartoe bereid rerklaarden is een zeer verblijdend teeken, en dit zal aan de snelle verbreiding der op deze wijze verkregen ervaring zeer ten goede komen.

Het aantal gewassen, dat op zijn geroeligheid roor car. bolineum beproefd is, is groot en telt vertegenwoordigers uit verschillende tuinbouwculturen, nl. vruchtencultuur, boomkweekerij en bloemisterij. Tot nu toe was echter het aantal gewassen, dat onder glas geteeld wordt en waarop proeven met carbolineum waren genomen, gering. Het lag thans op onzen weg te trachten, dit aantal uit te breiden.

Het eerst kwamen daarvoor in aanmerking de perzik en de druif, beide voor de glascultuur zeer belangrijke gewassen en waaraan door bepaalde insectensoorten belangrijke schade kan worden veroorzaakt. Indien het gelukte, voor deze vruchtboomen een onschadelijke behandeling met carbolineum vast te stellen, zou daarmede aan de praktijk een groote dienst worden bewezen. De parasieten toch, die op deze gewassen vrij vaak voorkomen en onder deze vooral de dopluis, waren tot nu toe alleen door een jaarlijks uitgevoerde, zorgvuldige behandeling te bestrijden, en in verscheidene gevallen gelukte dit zelfs nog maar onvolkomen, waarschijnlijk door de onvoldoende insectendoodende kracht der gebruikte middelen.

Ook het zorgvuldig afborstelen (al of niet gecombineerd met insmeeren met kalk, zwavel of eenig ander middel) 
leidde niet tot een afdoende bestrijding; en vooral bij de perzik was dit een zeer veel tijd eischend en daardoor kostbaar werk.

Te meer was de wenschelijkheid, om de bruikbaarheid van carbolineum op deze (in hoofdzaak) kasvruchten vast te stellen, groot, omdat de berookingen met blauwzuurdamp, waarvan in den aanvang veel verwacht werd, geen voldoend resultaat hadden opgeleverd. De verwachtingen, die van dit laatste middel gekoesterd werden, waren groot en niet zonder reden, want in Amerika en speciaal in de Westelijke staten, wordt het in steeds toenemende mate en met groote succès, toegepast. In ons land onder leiding van Dr. Quanjer beproefd, heeft het aanvankelijk ook gunstig gewerkt, zoodat het als bruikbaar middel reeds was aangenomen en het gebruik ervan voor de bestrijding van plantenparasieten, in verband met zijn groote giftigheid voor mensch en dier, bij Koninklijk Besluit van 10 Juli 1912 Stbl. No. 215 geregeld werd. Verscheidene, met evenveel zorg als de eerste, later uitgevoerde berookingen hebben echter een zeer onvoldoend resultaat opgeleverd, zoo zelfs, dat wij op dit oogenblik deze bestrijdingsmethode geheel hebben verlaten. Wat daarvan de oorzaak is, is ons nog niet bekend; en eigenaardig is het, dat een tweetal berookingen tegen bladluizen op de bollen in een bollenschuur, wèl een zeer gunstige uitkomst hebben opgeleverd.

De onvoldoendheid van alle tot nu toe ter bestrijding van de dopluis gebruikte middelen blijkt wel uit het volgende. Een tuinbaas wilde aan zijn personeel voor het afborstelen van perzikboomen vijf gulden per stuk betalen, nadat in het voorjaar gebleken zou zijn, dat de boomen werkelijk geheel vrij van dopluis waren. Op die voorwaarde wilde echter niemand het werk uitvoeren!

Voor behandeling met carbolineum bestond dan ook bij eenige vooruitstrevende tuinders in het Westland veel belangstelling, daar omtrent de werking van dit middel op 
de dopluizen geen twijfel bestond en de behandeling zelve zeer eenvoudig en zeer goedkoop zou zijn. De vraag was echter of de boomen de behandeling zouden verdragen, want vooral perzikboomen behooren tot de gevoelige gewassen.

Gelukkig waren er aanwijzingen, die deden verwachten, dat ook dit zou medevallen. Vooreerst was er reeds een enkele tuinder, die carbolineum gebruikte, maar dan in zeer verdunden toestand (2\%). Maar anderen gebruikten reeds sedert eenigen tijd petroleum, dat ook een krachtig insectendoodend middel is. De wijze waarop dit werd aangewend, was echter vrij onvoldoende, zoodat van een betere uitvoering niet alleen beter resultaat, maar ook minder kans op beschadiging kon worden verwacht.

$\mathrm{Na}$ een drietal lezingen, in het najaar van 1915 door mij te Wateringen, Monster en Naaldwijk gehouden, en waarop ik de gunstige werking van carbolineum op bessenstruiken en vruchtboomen besprak, verklaarden zich een zevental tuinders bereid, proeven met carbolineum te nemen op vruchtboomen in kassen. Bij allen werden perziken bespoten, terwijl een ook druiven en een ander pruimenboomen voor de proel beschikbaar stelde. De bespuiting bleef niet beperkt tot enkele boomen, maar in de meeste gevallen werd een geheele kas of een groot gedeelte ervan, ook wel meer dan een kas, behandeld. De bespuiting der druiven werd dadelijk op drie kassen toegepast.

In de meeste der behandelde kassen kwam dopluis (op de perzik Lecanimm corni Plaat XI fig. 3 en op de druif Pulinaria betulae fig. 2) in erge mate voor, soms zelfs zoo, dat de boomen in den zomer geheel bedekt waren met het "zwart" of roetdauw. Op enkele plaatsen was het minder de dopluis, dan wel het "spint" of ook de groene bladluis, die bestreden moest worden.

De uitvoering geschiedde in de meeste gevallen onder toezicht van een onzer; aan den heer Maarschalk, phytopatholoog 
aan het Instituut voor Phytopathologie mag hier wel een woord van dank gebracht worden voor de zorg, die hij aan de uitvoering besteedde, waardoor de uitkomsten zoo gunstig konden zijn. zoodat hij het gebruik van carbolineum in kassen in het Westland zeer krachtig heeft bevorderd. De gebruikte oplossingen waren te sterkte van $2-51 / 2 \%$ voor de perzik en van $4-8 \%$ voor de druif.

Bij de vermelding van de resultaten behoef ik niet in bijzonderheden af te dalen. Zij waren in alle opzichten zeer bevredigend en voor het nieuwe middel een volledig succès. Toch is het gewenscht hier eenige 'mededeelingen over te doen.

1. In een perzikkas, die „vergeven was door zwart" (zie dit artikel bl. 202), werd gespoten met een $5 \frac{1}{2} \%$ oplossing. Resultaat: dopluis gedood, zoodat de boomen zich prachtig ontwikkelden en zoo goed vruchten zetten, dat deze gedund moesten worden. In den zomer kon de eigenaar mij slechts twee kleine plekjes toonen, waar het zwart zich nog vertoonde. Deze waren gelegen in het laagste deel der boomen (leiperziken), en zeer duidelijk waren dit plekjes, die bij de bespuiting niet of minder goed geraakt waren. De groene luis was zoo goed las geheel verdwenen; spint was niet aanwezig.

2. In een kas bij een anderen eigenaar was gespoten met een $2 \%$ oplossing. Daar in deze kas reeds meermalen met carbolineum gespoten was, was dopluis afwezig. Het spint was echter niet voldoende bestreden.

3. Op een tuin waren perziken proefsgewijs bespoten met oplossingen, ter sterkte van 3,4 en $5 \%$, Geen enkele had geleden in den bloei, $3 \%$ en $4 \%$ bleken voor bestrijding van de bladluis niet voldoende, $5 \%$ wel.

4. Op een anderen plaats waren jonge perziken bespoten met 2, 3 en $5 \%$ oplossingen. Dopluis was niet aanwezig. De groene bladluis bleek met $2 \%$ onvoldoende, met $3 \%$ vrij goed en met $5 \%$ goed te zijn bestreden. 
Perziken, tegen een muur geplaatst, waren bespoten met een $6 \%$ oplossing. Bladluis trad nog zeer weinig op, spint daarentegen veel. De boomen waren wel losgemaakt, vóór zij bespoten werden, maar de muur was niet bespoten. Blijkbaar heeft een aantal mijten, die het spint veroorzaken, in reten in de muur overwinterd of waren daarop eieren gelegd, die overgebleven zijn.

Bij denzelfden tuinder werden de druiven in 3 kassen bespoten. De boomen werden geheel losgemaakt en aan twee zijden bespoten met 4 , 6 en $8 \%$ oplossingen. De $4 \%$ oplossing had weinig geholpen, de $6 \%$ veel beter en de $8 \%$ oplossing was afdoende. Op een boom, die blijkbaar overgeslagen was, trad de dopluis even sterk op, als vroeger in de geheele kas.

5. Op een anderen tuin werd met een $2 \%$ oplossing gespoten tegen de dopluis op de perzik. De bespuiting had wel eenige uitwerking, maar niet voldoende. Een $4 \%$ oplossing gaf daar veel beter resultaat, zonder dat de bloei of het uitloopen der boomen benadeeld werden.

Een Victoriapruim, door denzelfden tuinder met een $5 \%$ oplossing bespoten, bleef geheel vrij van luis.

6. Bij een anderen tuinder had een $2 \%$ oplossing tegen de bladluis op perzik geen resultaat gehad.

7. Ten slotte gaf een 5\% oplossing op perzik tegen de dopluis een volkomen afdoend resultaat. De dopluis was geheel verdwenen. De bladluis kwam slechts op enkele takjes terug. De vruchtzetting was hier uitstekend.

Deze bespuitingen hebben dus geleerd:

1e. dat de perzik een 5\% oplossing, zonder eenige schade kan verdragen en dat zelfs een nog sterkere oplossing niet schadelijk behoeft te zijn;

2e. dat een $5 \%$ carbolineumoplossing tegen de dopluis op perzik vrijwel afdoende resultaten geeft en dat ook degroene bladluis en het spint op zeer goede wijze daarmede worden bestreden. Minder sterke oplossingen geven duidelijk minder 
resultaat. Een $2 \%$ oplossing is vrijwel zonder uitwerking; 3e. dat de druif een $6-8 \%$ carbolineumoplossing zonder schade kan verdragen en dat daarmede de dopluis afdoende kan worden bestreden.

Alle hierboven aangehaalde bespuitingen zijn uitgevoerd in het einde van December of in Januari. De gebruikte hoeveelheden vloeistof waren niet zeer groot, maar voldoende om de boomen flink te bevochtigen. 30-40 L. sproeivloeistof waren voldoende tot bespuiting van een tweezijdige perzikkas van $32 \mathrm{M}$. lengte.

In de gevallen, waarin een boom (b.v. een druiveboom) blijkbaar was overgeslagen, werd de gunstige werking van het carbolineum eerst duidelijk gedemonstreerd. Bij latere proefnemingen is dit ook waargenomen en is het hier en daar voorgekomen, dat jonge, pas ingeplante boomen bij de bespuiting waren overgeslagen. De arbeider had blijkbaar al zijn aandacht aan de behandeling der oudere boomen gewijd en de jonge, die geen of weinig vrucht zouden voortbrengen, overgeslagen. Op deze kwam het zwart dan zeer veel voor, terwij1 ook de naaststaande boomen met de overgeloopen jonge dopluizen waren bezet en ook eenigszins met zwart waren bedekt. Om een afdoend resultaat te verkrijgen, mag dan ook geen plant en geen gedeelte van een plant zelfs worden overgeslagen.

Het is mij gebleken, dat in den winter 1915/16 nog meer proeven met carbolineum genomen zijn, dan hierboven zijn vermeld en in den afgeloopen winter is dit aantal nog uitgebreid. De resultaten zijn van dien aard, dat velen thans met volledig vertrouwen hun perzik-en druiveboomen met dit middel bespuiten, en het laat zich aanzien, dat het gebruik nog algemeener zal worden. Ik juich dit zeer toe, daar er geen middel tegen verschillende dierlijke parasieten op deze boomen bestaat, dat meer afdoend en tegelijkertijd even goedkoop is. Het is echter gewenscht, dat allen, die het zullen toepassen, met de ervaringen. die onder andere 
omstandigheden zijn verkregen, bekend zijn. Uit de hierboven genoemde proeven kunnen deze niet afgeleid worden, aangezien die zonder uitzondering zonder eenig nadeel voor de planten verliepen. Later uitgevoerde, afwijkende behandelingen hebben onze kennis echter uitgebreid.

Vooreerst is het beslist verkeerd gebleken, druiveboomen met een carbolineumoplossing in te smeren. Dit was mij uit een andere proetneming reeds bekend en op mijn lezingen in het Westland heb ik daarvoor uitdrukkelijk gewaarschuwd. Het insmeren van een druiveboom (met zwavel kalk) zit den Westlander echter in het bloed, zoodat een tuinder te Naaldwijk, ondanks een waarschuwing van den eersten proefnemer met druiven, zijn boomen toch insmeerde met carbolineum. Het gevolg was, dat zijn boomen onregelmatig uitliepen en vele knoppen bleven „zitten.”

Ook is het gewenscht, op de perzik geen oplossingen te gebruiken van een sterkte van meer dan $5 \%$. Proefgewijs of bij vergissing zijn op enkele plaatsen sterkere oplossingen gebruikt, b.v. $7 \frac{1}{2} \%$, maar deze hadden meestal duidelijk een nadeeligen invloed op den bloei; de bloemknoppen waren beschadigd. Hetzelfde is het geval, als de bespuiting te laat wordt uitgevoerd. Zoodra er eenige werking in de bloemknoppen is gekomen en deze dus beginnen te zwellen, mogen perzikboomen niet meer met carbolineum bespoten worden. In de gevallen, waarin dit geschiedde, ontwikkelden de bladknoppen zich nog wel goed en groeiden de scheuten soms zelfs zeer goed, maar de bloem was verloren. Vroeger spuiten dan eind December is voor late perziken ook verkeerd.

Ten slotte moet men er goed op letten, dat men een goede carbolineumsoort voor deze bespuitingen gebruikt. Carbolineum dat men zelf oplosbaar maakt, is voor perzik en druif ongeschikt. Maar alle zgn. oplosbare carbolineum is ook nog niet te gebruiken. De soorten, die bij verdunning met water niet helderwit worden, dus bruin blijven, zijn 
te wantrouwen, aangezien deze gewoonlijk op de boomen een bruine, glimmende laag achterlaten, die blijkbaar een schadelijken invloed op de ontwikkeling der knoppen uitoefent. Carbolineumsoorten die een helder witte oplossing geven, als men ze met water verdunt en die geen aanslag op de boomen achterlaten, zijn voor de bespuiting van perzik- en druiveboomen, volgens de opgedane ervaringen, wel geschikt. Een paar bruine droppeltjes, die soms op de overigens helderwitte vloeistof blijven drijven, zijn blijkbaar niet nadeelig.

Dat de bestrijding van dopluis met carbolineum zeer gunstig werkt, blijkt uit de qualiteit der geoogste vruchten. In kassen, waarin het "zwart" voorkomt, groeien vooral de perziken zeer onvoldoende uit en zijn zij bedekt met een roetachtige massa. De qualiteit der vruchten is slecht. Druiven hebben, wat den groei betreft, gewoonlijk niet zooveel te lijden als perziken, maar hier is het alweer het „zwart," dat de trossen onbruikbaar maakt.

De dopluizen zijn dan ook in tweeërlei opzicht schadelijk:

1o. onttrekken zij sappen aan de planten door haar zuigen;

2o. scheiden zij vloeibare uitwerpselen af, die eerst oorzaak zijn van het optreden van honigdauw en spoedig daarna van roetdauw of zwart.

Dit laatste is, zooals hierboven werd aangegeven, bijzonder schadelijk. De vloeibare uitwerpselen worden door de dopluizen (en ook door bladluizen) in droppeltjes afgescheiden. Deze droppeltjes vallen op de lager geplaatste deelen van den boom, bladeren, takken en vruchten, en overdekken deze met een vettig, doorschijnend laagje, den zgn. honigdauw. $\mathrm{Nu}$ vestigt zich gewoonlijk in dien honigdauw zeer spoedig een donkergekleurde zwam, die dus niet van de planten leeft, maar haar voedsel uitsluitend haalt uit die vloeibare uitwerpselen. Alle deelen, die met honigdauw bedekt zijn, worden dus ook door de groeiende schimmel 
bedekt, vandaar dat overal een zwarte, roetachtige laag ontstaat, die wel van de vruchten en bladeren kan worden afgewreven, maar de eerstgenoemden toch zeer onooglijk maakt.

Op het blad oefent deze roetdauw nog vaak een zeer nadeeligen invloed uit. Is de zwarte laag dik, dan sluit deze het blad geheel van het zonlicht af. In vele gerallen verliezen plantendeelen, die in het donker verkeeren, hun groene kleur en worden zij voor de voeding van de plant (die alleen in het zonlicht mogelijk is) zonder waarde. Dit kan ook door den roetdauw veroorzaakt worden. Op plaat XI fig. I vindt men een druiveblad a fgebeeld, dat grootendeels bedekt is met roetdauw. Alleen een deel van de rechterzijde en een plek op de linkerzijde (die iets lichter getint zijn) zijn ervan vrij. In het midden vooral is de zwarte laag dik. Deze is nu gedeeltelijk ervan verwijderd. Het blad daaronder is geheel geel (geëtioleerd) en heeft dit dus voor de voeding van de plant in het geheel geen waarde meer. Het is daarom duidelijk, dat een sterke bedekking met roetdauw den groei van den boom en vooral den aanleg van knoppen ten zeerste benadeelt en dus het kaalworden en afsterven van takken in de hand werkt.

N. vin Poeteren.

Wrgeningen, November 1917.

\section{VERKLARING DER AFBEELDINGEN}

Plaat XI.

Fig. 1, Druiveblad, grootendeels met roetdauw (zwart) bedekt. In het midden is deze verwijderd; daaronder is het blad geel (de lichte vlekken).

Fig. 2, Druivetakje met dopluis (Pulvinaria betulae). De donkere stukjes op de witte wasdradenmassa's zijn pas uit het ei gekomen dopluisjes.

Fig. 3, Perziktakjes, bezet met dopluis (Lecanium corni). 